Raf. J. Sci.,Vol.28, No.2 Special Issue for the Third Scientific Conference of Chemistry, pp.23-36, 2019

\title{
Preparation, Characterization and Biological Activities of some Unsymmetrical Schiff Bases Derived from m-phenyelenediamine and their Metal Complexes
}

\author{
Moza M. Al- Jiboury \\ Khansaa Sh. Al- Nama \\ Department of Chemistry/ College of Science/ University of Mosul \\ E-mail: mmohammedsaleh9@gmail.com_E-mail: al-numa3@yahoo.com*
}

(Received 8/7/2018;Accepted 25/10/2018)

\begin{abstract}
Unsymmetrical Schiff bases $\mathbf{H}_{\mathbf{2}} \mathbf{L}^{\mathbf{1}}=[1-((\mathrm{E})-((\mathrm{3}-(((\mathrm{E})-2-$ hydroxybenzylidene $)$ amino)phenyl)imino)methyl) naphthalene-2-ol] and $\mathbf{H}_{2} \mathbf{L}^{2}=[1-((\mathrm{E})-((3-(((\mathrm{E})-1-(2-$ hydroxphenyl $)$ ethylidene ) amino ) phenyl ) imino ) methyl ) naphthalene - 2-ol ] which derived from $m$ phenylenediamine and 2-hydroxynaphthaldehyde and then with salicyaldehyde or 2hydroxyacetophenone, and their complexes of the type $\left[\mathrm{M}_{2} \mathrm{~L}^{\mathrm{n}}{ }_{2}\right]$, where $\mathrm{n}=1,2$ and $\mathrm{M}=$ $\mathrm{Mn}(\mathrm{II}), \mathrm{Co}(\mathrm{II}), \mathrm{Ni}(\mathrm{II})$ and $\mathrm{Cu}(\mathrm{II})$ have been synthesized. Adduct complexes of the type $\left.\left[\mathrm{M}_{2} \mathrm{~L}_{2}{ }_{2} \text { (py) }\right)_{4}\right]$ were also prepared in $(1: 4)($ complex : py) molar ratio. The complexes and adducts were characterized by elemntal analysis (C. H. N), metal content, (IR, UV-v.s, ${ }^{1} \mathrm{H}-\mathrm{NMR}$ ) spectroscopy, conductivity and magnetic measurements. The resulted data suggested that the Schiff bases containing ONNO donor atoms acts as dibasic tetradendetate ligands through coordinated with metal ions. Conductivity data in DMSO solution showed that all complexes are non- electrolyte. Magnetic moment and electronic spectra data indicat that the complexes have either tetrahedral or octahedral geometry while $\left[\mathrm{Ni}_{2} \mathrm{~L}_{2}^{\mathrm{n}}\right]$ complexes have square planer geometry. The legends and their complexes were screened for antibacterial activity against Staphylococcus-aureus and Escherichia coli. The ligands and their complexes showed some biological activities.
\end{abstract}

Keywords: Antibacterial activity, m-phenylenediamine, Schiff base, Unsymmetrical tetradentate.
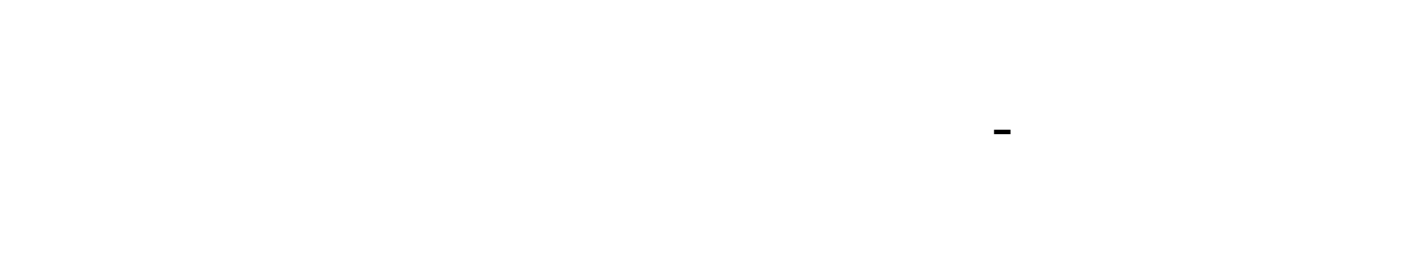

$\mathrm{H}_{2} \mathrm{~L}^{1}=[1-((\mathrm{E})-((3-()((E)-2-$ hydroxybenzylidene) amino)phenyl)imino)methyl) naphthalene- 2- ol], $\mathrm{H}_{2} \mathrm{~L}^{2}=$ [1-((E)-((3-(((E) -1- (2 - hydroxphenyl) و (m- phenylenediamine والمثقة a ethylidene) amino) phenyl) imino) methyl) naphthalene - 2 - ol], $\left[\mathrm{M}_{2} \mathrm{~L}_{2}{ }_{2}\right]$ او 2-hydroxyacetophenone Salicyaldehyde 2 - hydroxynaphthaldehyde

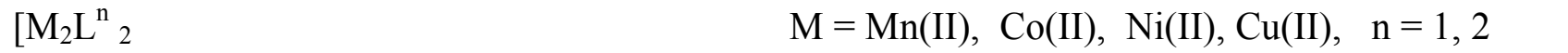

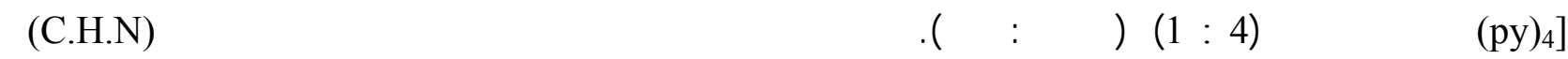

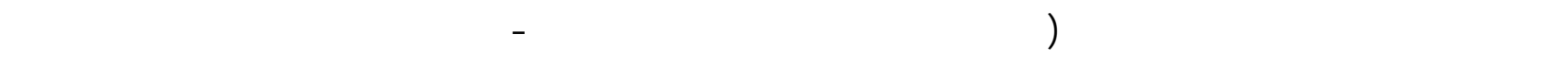

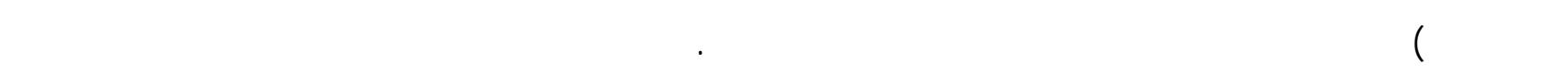

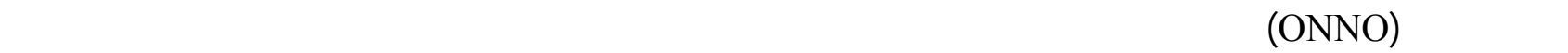




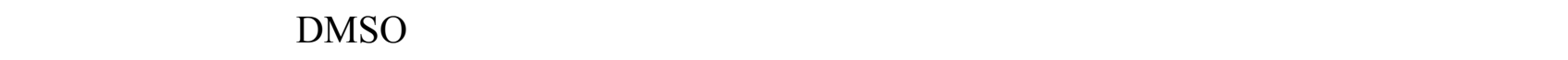

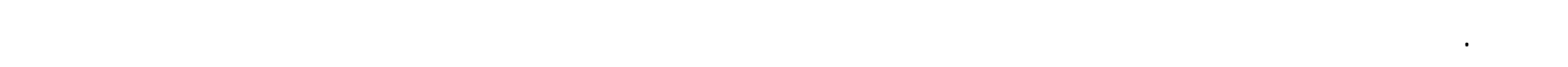

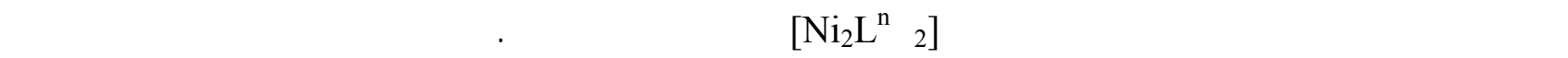

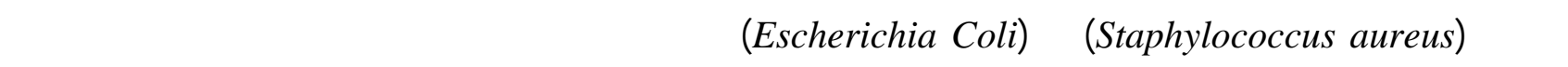

الكالمل الدالة: الفهوالية المهيز ادة للبكتريا، ميتا - فنيلين ثنائي المين، قواء د شيف، رباعية المنح غير المتماثلة.

INTRODUCTION

Both symmetrical and unsymmetrical Schiff bases have been widely used as ligands to prepare metal complexes (Prakash et al., 2011). These complexes have played a major role in the advancement of coordination chemistry whose field of application varies from physicochemical studies (Luo et al., 2003), to biological aspects (El-Motalb et al., 2011).

In biological systems, transition metal ions are usually bound to a macrocycle such as a heme ring or to donor atoms of peptide chains in distorted enviromment (Li et al., 2015), and this unsymmetrical coordination of ligands around central metal ions had lead to a growing interest in the design and synthesis of transition metal complexes of unsymmetrically substituted Schiff base ligands as synthetic models (Hernandez et al., 2004).

Aromatic diamines have the ability to coordinate to a metal directly on their relative ortho, meta or para positions (Hernandez et al., 1997), $m$ - phenyelenediamine derived Schiff bases can only coordinate one nitrogen atom to any metal ion. This is due to the big proximity range between the nitrogen atoms of $m$ - phenylenediamine and its rigid structure (Torayama et al., 1998).

Generally, $m$-phenylenediamine Schiff bases have the ability to acquire the formation of dimer complexes, where the Schiff bases act as bridges connecting the two metal cations (Clarke et al., 1998) thus producing dinuclear complexes. The uniqueness of such behaviour however has never been applied and studied in the biological field as compared the Schiff bases derived from the other two aromatic diamines namely its ortho and para-analogues. Such complexes were suggested to have an even better biological activity due to the presence of two metal ions compared to complexes with one metal ion. Therefore synthesis, characterization and the biological activity of two unsymmetrical tetradentate Schiff bases derived from $m$-phenylenediamine and their $\mathrm{Mn}(\mathrm{II}), \mathrm{Co}(\mathrm{II}), \mathrm{Ni}(\mathrm{II})$ and $\mathrm{Cu}(\mathrm{II})$ complexes are described in this work.

\section{EXPERIMENTAL}

All reagents and solvents were of analytical grade used as supplied from fluka or BDH chemical companies, Infrared spectra were recorded on BRUKER mauf. U.K. (400$4000 \mathrm{~cm}^{-1}$ ) using $\mathrm{KBr}$ disc. Conductivity measurements were carried out on $\left(10^{-3}\right) \mathrm{M}$ solution of the complexes in DMSO using Conductivity meter Model PCM3 - JENWAY at ambient temperature. The electronic spectra were recorded in DMSO $\left(10^{-3}\right) \mathrm{M}$ solution on SPECTRO UV-VIS AUTO, 110 v $60 \mathrm{HZ}$ using $1 \mathrm{~cm}$ quartz cell (200-1000)nm. Metal content was determined using instrument, AA-7000- UN. BG. IBN- H.C.S.L Atomic Absorption (Flamecont). Elemental analysis were performed on Euro EAE Elemental Analyzer Euro EA 3000 Italy. ${ }^{1}$ H-NMR Spectra were recorded in DMSO - $\mathrm{d}_{6}$ using NMR edy 60 prrouser, Manual Version 1.0 (Nanalysis Crop, 2015). Melting point was recorded on Electro - thermal 9300 Engineering LT D. The magnetic measurements were carried out at $25{ }^{\circ} \mathrm{C}$ on the solid state by (Magnetic Susceptibility Balance Sherwood Scientific Cambridge / U K). 


\section{Preparation of the Legends}

The unsymmetrical Schiff base ligands were prepared according to the reported procedure (Pethe et al., 2017) by reacting equimolar amounts of $m$-phenylenediamine $(0.01$ mole $, 1.08 \mathrm{~g})$ in methanol $(10 \mathrm{ml})$ was added slowly to methanolic solution $(10 \mathrm{ml})$ containing 2- hydroxynaphthaldehyde $(0.01 \mathrm{~mole}, 1.72 \mathrm{~g})$ and refluxed for $1 \mathrm{~h}$, then fllowed by addition of salicyaldehyde $(0.01$ mole, $1.22 \mathrm{~g})$ or 2- hydroxyacetophenone $(0.01$ mole, $1.36 \mathrm{~g})$, each one dissolved in methanol $(10 \mathrm{ml})$, the resulting coloured mixture was refluxed with stirring for $4 \mathrm{~h}$ and cooled, then the precipitate was filtered off and washed with cold methaol and dried under vacuum, (Schem 1 ).
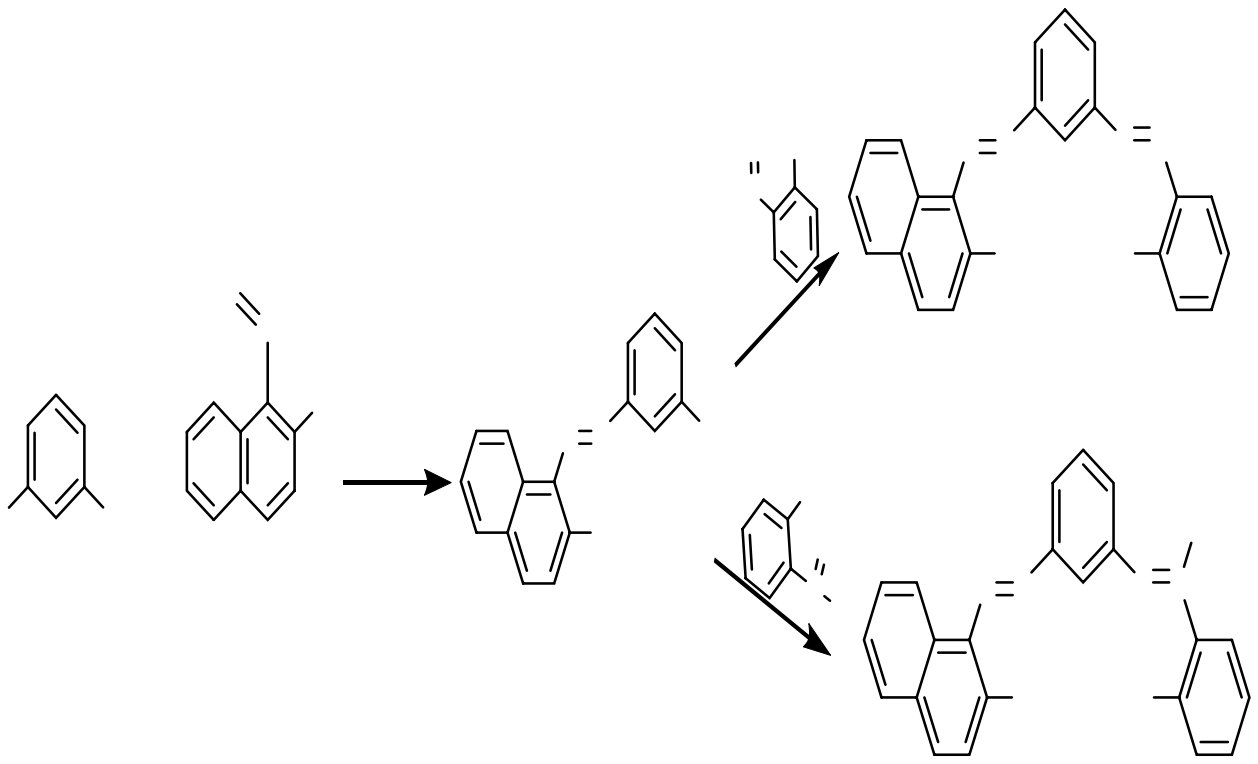

\section{Preparation of the Complexes}

The ligands $\mathrm{H}_{2} \mathrm{~L}^{1}(0.01$ mole, $3.66 \mathrm{~g})$ or $\mathrm{H}_{2} \mathrm{~L}^{2}(0.01$ mole, $3.80 \mathrm{~g})$ was dissolved in methanol $(30 \mathrm{ml})$ in $100 \mathrm{ml}$ round bottom flask. A solution of metal chloride $(0.01 \mathrm{~mole})$ [ $\mathrm{MnCl}_{2} .4 \mathrm{H}_{2} \mathrm{O}(1.97 \mathrm{~g}), \mathrm{CoCl}_{2} \cdot 6 \mathrm{H}_{2} \mathrm{O}(2.37 \mathrm{~g}), \mathrm{NiCl}_{2} \cdot 6 \mathrm{H}_{2} \mathrm{O}(2.37 \mathrm{~g}), \mathrm{CuCl}_{2} \cdot 2 \mathrm{H}_{2} \mathrm{O}$ (1.70 g) ] in methanol $(20 \mathrm{ml})$ was added drop wise for $10-15 \mathrm{~min}$. with continues stirring at room temp. The mixture was refluxed for $(3-4) \mathrm{h}$, after cooling the precipitate filtered off and washed with cold methanol then dried under vacuum.

\section{Preparation Base Adduct Complexes $\mathrm{CH}$}

These complexes were prepared by the addition of pyridine $(0.04$ mole, $3.16 \mathrm{~g})$ to $(0.01$ mole) the prepared complexes in methanol $(50 \mathrm{ml})$ with continuous stirring until complete precipitation. The precipitate was filtered off, washed with cold methopol and dried under vacuum (Osowole, 2008).

\section{Antibacterial Activity}

Antibacterial activity was evaluated using agar diffusion method (2hethcum, 1988), Gram - positive bacteria Staphylococcus aureus and Gram-negative bacteria Escherichia coli

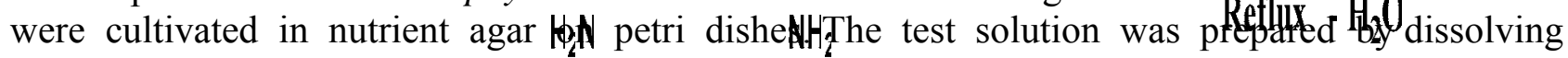
$(10 \mathrm{mg})$ of the tested substances in DMSO $(1 \mathrm{~mL})$. A6 mm diameter filter discs were socked in the tested solutions. After $24 \mathrm{~h}$ cultivation at $37{ }^{\circ} \mathrm{C}$, diameter $\mathrm{gf}$ zones of inhibition was

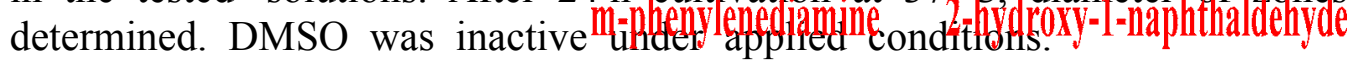




\section{RESULTS AND DISCUSSION}

All the metal complexes are quite stable in dry air and insoluble in common organic solvents but soluble in DMF and DMSO. The elemental analysis shows $(2: 2)(\mathrm{M}: \mathrm{L})$ molar ratio for $\left[\mathrm{M}_{2} \mathrm{~L}^{\mathrm{n}}{ }_{2}\right]$ and $(2: 2: 4)\left[\mathrm{M}: \mathrm{L}^{\mathrm{n}}\right.$ : py] molar ratio for $\left[\mathrm{M}_{2} \mathrm{~L}_{2}{ }_{2}(\mathrm{PY})_{4}\right]$. Some physical properties of ligands and their complexes are listed (Table 1.). The molar conductance in $\left(10^{-3}\right) \mathrm{M}$ DMSO solution of complexes are in the range $(14.4-20.0) \mathrm{ohm}^{-1} \mathrm{~cm}^{2} \mathrm{~mol}^{-1}$, indicating a non electrolytic nature of the complexes (Gerry, 1971).

\section{Infrared Spectra}

The IR Spectrum of the free ligands was studied and assigned on the bases of careful comparison of the complex spectra with that of the free legends, (Table 2). The IR Spectrum of the ligand show characteristic band at (3465 and 3498) $\mathrm{cm}^{-1}$ attributed to the phenolic hydroxyl group in $\mathrm{H}_{2} \mathrm{~L}^{1}$ and $\mathrm{H}_{2} \mathrm{~L}^{2}$ respectively (Alias et al., 2014). The absence of this band in the spectra of the complexes indicates the coordination of phenolic oxygen to the metal ion after deprotonation (Pethe et al., 2017). This is further supported by the shifting of $v(\mathrm{C}-\mathrm{O})$ phenolic band to lowers frequency $(1245-1273) \mathrm{cm}^{-1}$ in the spectra of all complexes (Nagajothi et al., 2013). The IR spectrum of $\left(\mathrm{H}_{2} \mathrm{~L}^{1}\right.$ and $\left.\mathrm{H}_{2} \mathrm{~L}^{2}\right)$ show band at (1612 and 1582$) \mathrm{cm}^{-1}$ due to $\mathrm{U}(\mathrm{C}=\mathrm{N})$ stretch. On complexation this band shifted to higher frequency in all complexes by $(10-34) \mathrm{cm}^{-1}$ indicating participation of azomethine nitrogen in complexation (Ramesh et al., 1996). The stretching vibration of $\mathrm{v}(\mathrm{C}=\mathrm{N})$ bond of pyridine ring was obsorved at the region (1484-1506) $\mathrm{cm}^{-1}$ in complexes $(5,6,7,8,13,14,15$ and 16) which indicates the coordination of the nitrogen atom of pyridine ring with the metal ions (Ceraldo et al., 2011). Some new bands apper in the spectra of the complexes which include of the stretching vibrations of $v(\mathrm{M}-\mathrm{N})$ and $v(\mathrm{M}-\mathrm{O})$. These bands apper in the ranges (417463) $\mathrm{cm}^{-1}$ and (491 - 553) $\mathrm{cm}^{-1}$ respectively (Pathan et al., 2012). The I.R Spectra of ligands and $\mathrm{Mn}(\mathrm{II}), \mathrm{Cu}(\mathrm{II})$ have been shown Fig. (1).

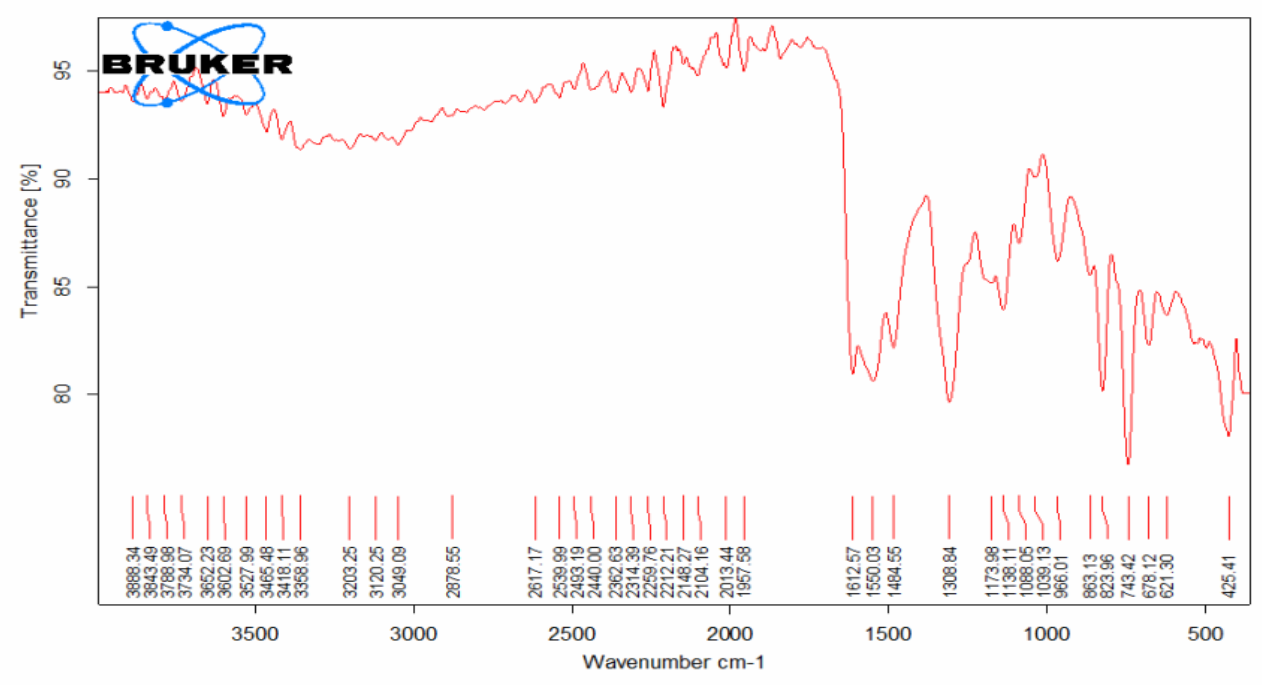




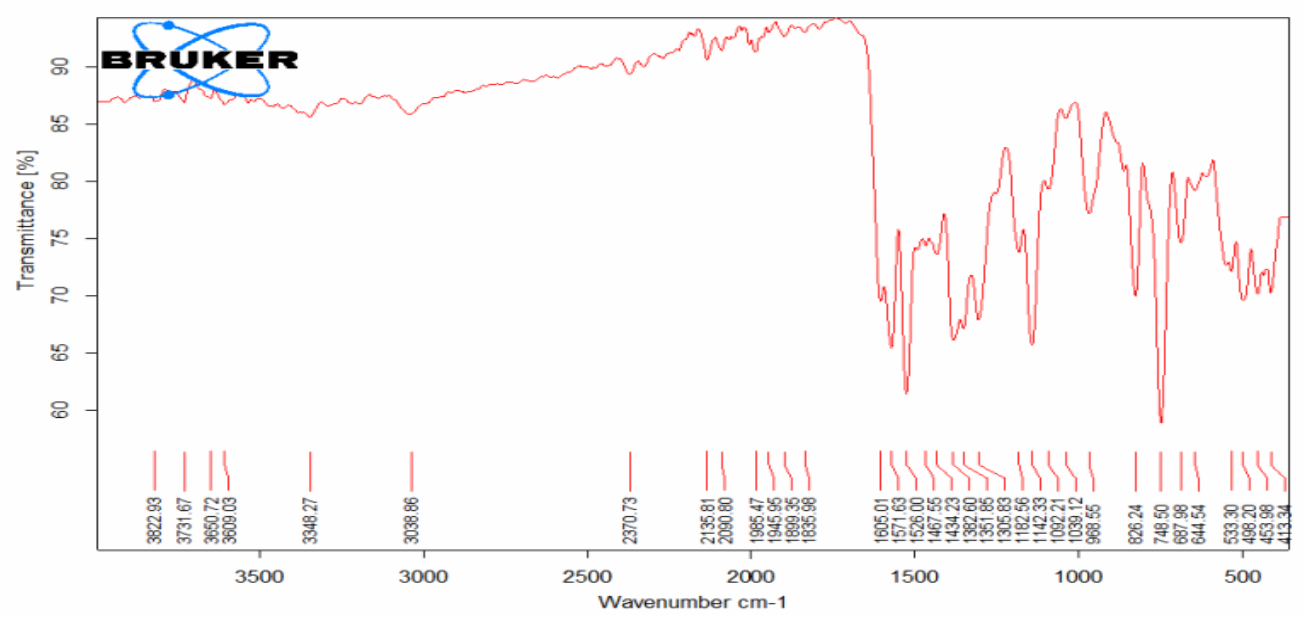

(b)

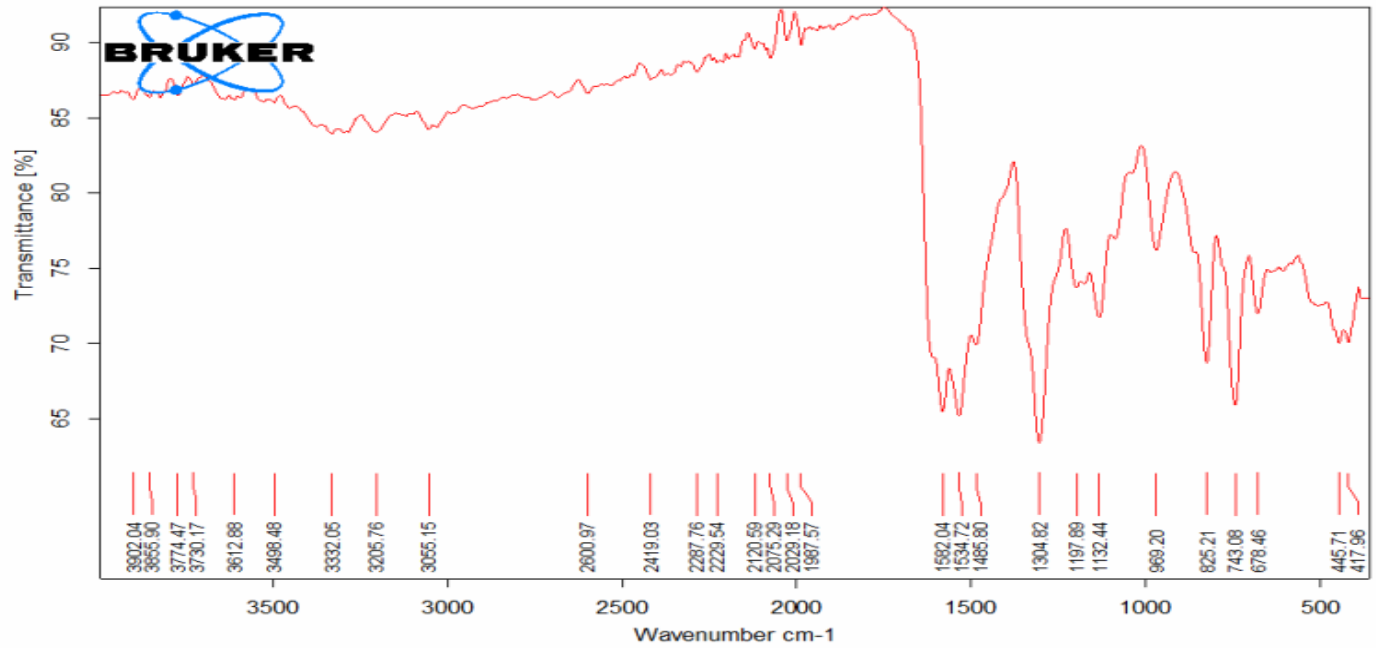

( c)

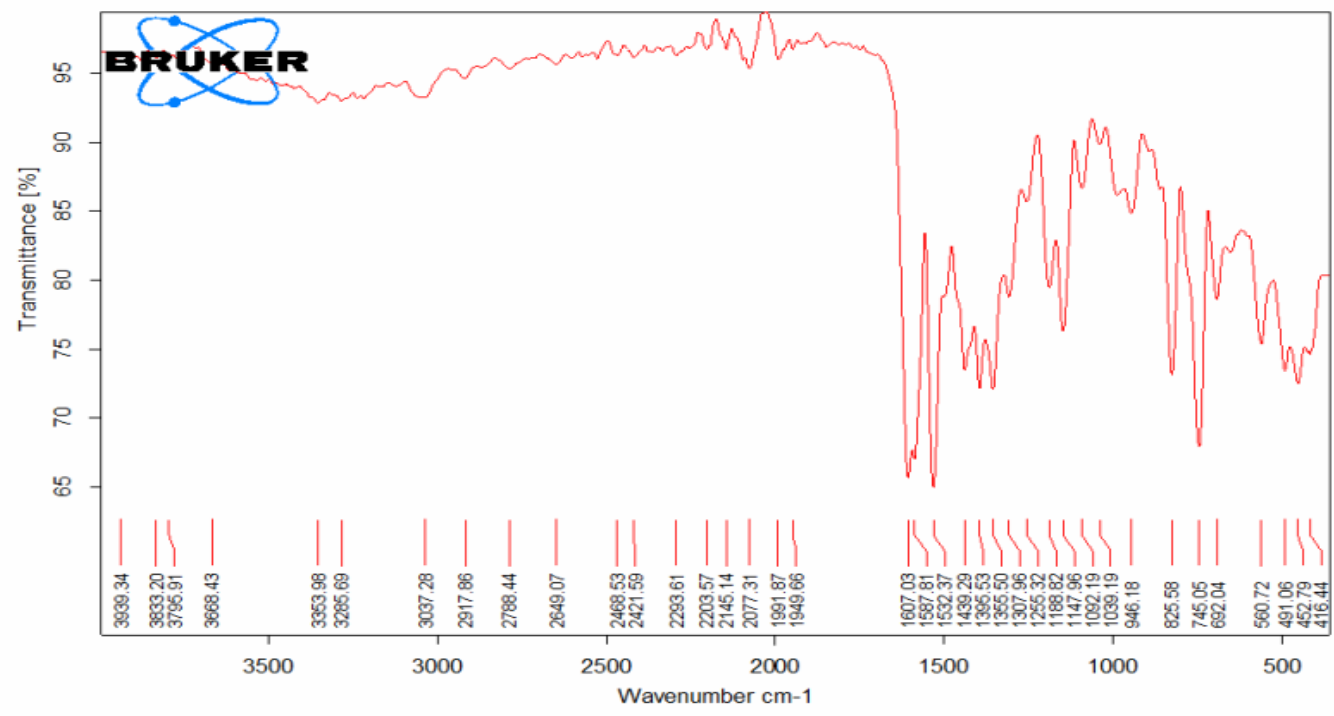

(d)

Fig. 1: IR - Spectra of (a) $\mathrm{H}_{2} \mathrm{~L}^{1}$ (b) $\left[\mathrm{Mn}_{2} \mathrm{~L}^{1}{ }_{2}\right]$ (c) $\mathrm{H}_{2} \mathrm{~L}^{2}$ and (d) $\left[\mathrm{Cu}_{2} \mathrm{~L}^{2}{ }_{2}\right]$ 


\section{Electronic Spectra and Magnetism}

The magnetic moments and electronic spectra data at $25{ }^{\circ} \mathrm{C}$ of the ligands and their complexes are listed (Table 3). The electronic spectra of the ligands $\mathrm{H}_{2} \mathrm{~L}^{1}$ and $\mathrm{H}_{2} \mathrm{~L}^{2}$ in DMSO solution show intense bands at $(37037,37313) \mathrm{cm}^{-1}$ and $(31446,31545) \mathrm{cm}^{-1}$ attributed to benzene $\pi \rightarrow \pi^{*}$ and $\mathrm{n} \rightarrow \pi^{*}$ transition of the non-bonding electrons present on the nitrogen of the azomethine group respectively, these transitions are also found in the spectra of the complexes but they are shifited to confirmed the coordination of the ligand to the metal ion (Elmali et al., 2005). New bands in spectra of all complexes at range (26993-29411) $\mathrm{cm}^{-1}$ may be associated with the charge transfer transition (Aranha et al., 2016). The dinuclear $\mathrm{Mn}$ (II) complexes (1,5,9 and 13) show magnetic moment values at the range (5.75 - 5.90) B.M, which are appreciably close to the calculated spin - only value (5.91) B.M, for five unpaired electrons and reveals a high spin state (Cotton et al., 1999). The electeonic sprctra of extremely pale colour high spin Mn (II) complexes don 't show any $d-d$ transitions bands due to spin forbidden as well as parity -forbidden transitions in tetrahedral and octahedral environments (Cotton et al., 1999 ; Al-Kattan and Al-Nidaa, 2013), therefore, the structures of the prepared $\mathrm{Mn}(\mathrm{II})$ complexes were proposed depending on the data of other measurements namely metal content and IR spectra.

The magnetic moment values of dinuclear Co(II) complexes $(2,10)$ are $(3.81$ and 3.79) B.M, and their electronic spectra exhibit an abservation peak at (16393 and 16260) $\mathrm{cm}^{-1}$ region which was assigned to ${ }^{4} \mathrm{~A}_{2}(\mathrm{~F}) \rightarrow{ }^{4} \mathrm{~T}_{1}(\mathrm{P})$ transition, and the absence of ${ }^{4} \mathrm{~A}_{2}(\mathrm{~F}) \rightarrow{ }^{4} \mathrm{~T}_{2}(\mathrm{~F})$ and $\left({ }^{4} \mathrm{~A}_{2}(\mathrm{~F}) \rightarrow{ }^{4} \mathrm{~T}_{1}(\mathrm{~F})\right.$, are due to the sensitivity of the instrument used, the magnetic measurement and the electronic spectra of these complexes indicating a tetrahedral geometry (Ejidike et al., 2015). The magnetic moment values of dinuclear Co(II) complexes $(6,14)$ are $(5.75$ and 5.80) B.M, and their electronic spectra showed bands at $(16806,21052$ ) $\mathrm{cm}^{-1}$ and $(15480,21276) \mathrm{cm}^{-1}$ assigned to ${ }^{4} \mathrm{~T}_{1} \mathrm{~g}(\mathrm{~F}) \rightarrow{ }^{4} \mathrm{~A}_{2} \mathrm{~g}(\mathrm{~F})$ and ${ }^{4} \mathrm{~T}_{1} \mathrm{~g}(\mathrm{~F}) \rightarrow{ }^{4} \mathrm{~T}_{1} \mathrm{~g}(\mathrm{P})$ respepectively, these observation indicats an octahedral geometry around $\mathrm{Co}$ (II) ions (Siddiqi et al., 2007).

The magnetic measurements indicates that dinuclear $\mathrm{Ni}$ (II) complexes $(3,11)$ are diamagnetic and the electronic spectra of these complexes showed two bands at (18518, 24396) $\mathrm{cm}^{-1}$ and $(16666,24096) \mathrm{cm}^{-1}$, which assigned to ${ }^{1} \mathrm{~A}_{1} \mathrm{~g} \rightarrow{ }^{1} \mathrm{~A}_{2} \mathrm{~g}$ and ${ }^{1} \mathrm{~A}_{1} \mathrm{~g} \rightarrow \mathrm{B}_{1} \mathrm{~g}$ trasition respectively, these results suggest a square planar geometry around Ni (II) (Raman et al., 2007), while the magnetic measurements of complexes $(7,15)$ were found to be (2.92 and 2.79) B.M, and the electronic spectra of these complexes show two bands at $(21186,24271) \mathrm{cm}^{-1}$ and $(20618,23529) \mathrm{cm}^{-1}$ assigned to ${ }^{3} \mathrm{~A}_{2} \mathrm{~g}(\mathrm{~F}) \rightarrow{ }^{3} \mathrm{~T}_{1} \mathrm{~g}(\mathrm{~F})$ and ${ }^{3} \mathrm{~A}_{2} \mathrm{~g}(\mathrm{~F})$ $\rightarrow{ }^{3} \mathrm{~T}_{1} \mathrm{~g}(\mathrm{p})$ transition respectively, which indicating an octahedral geometry around the Ni(II) ions. (Jayaseelan et al., 2011; Al-Daher et al., 2018).

The obtained magnetic moment values of $\mathrm{Cu}$ (II) complexes $(4,8,12$ and 16) has been found in the range $(1.83-2.20)$ B.M, which indicate the presence of one unpaired electron for $\mathrm{Cu}$ (II). The electronic spectra of $\mathrm{Cu}$ (II) complexes $(4,12)$ showed a broad band at $(10686,10566) \mathrm{cm}^{-1}$ attributed to ${ }^{2} \mathrm{~T}_{2} \rightarrow{ }^{2} \mathrm{E}$ transition which is comparable with complexes having a tetrahedral structure (Turan et al., 2009), while complexes $(8,16)$ showed a broad absorption band at $(151515,15625) \mathrm{cm}^{-1}$ arises due to $\mathrm{d}-\mathrm{d}$ transition ${ }^{2} \mathrm{Eg} \rightarrow{ }^{2} \mathrm{~T}_{2} \mathrm{~g}$ suggest that the $\mathrm{Cu}$ (II) ion exhibits an octahedral geometry (Jayaseelan et al., 2010).

\section{${ }^{1}$ H-NMR - Spectra of Ligands}

The ${ }^{1} \mathrm{H}-\mathrm{NMR}$ - Spectra of free ligands at room temperature in DMSO $-\mathrm{d}_{6}$ shows the following signals (Garces et al., 1988).

For $\mathrm{H}_{2} \mathrm{~L}^{1}: \delta=12.95 \mathrm{ppm}(\mathrm{s}, 2 \mathrm{H}$, phenolic), $\delta=(6.89-8.55) \mathrm{ppm}(\mathrm{m}, 14 \mathrm{H}$, Aromatic), $\delta=9.03 \mathrm{ppm}$ ( $\mathrm{s}, 2 \mathrm{H}$, azomethine).

For $\mathrm{H}_{2} \mathrm{~L}^{2}: \quad \delta=3.51 \mathrm{ppm}(\mathrm{s}, 3 \mathrm{H},-\mathrm{CH} 3), \delta=9.70 \mathrm{ppm}(\mathrm{s}, 2 \mathrm{H}$, phenolic), $\delta=(6.89-8.45) \mathrm{ppm}$ $\left(\mathrm{m}, 14 \mathrm{H}\right.$, Aromatic), $\delta=8.55 \mathrm{ppm}$ (s, 1H, azomethine). The ${ }^{1} \mathrm{H}-\mathrm{NMR}$ - Spectra of ligands have been shown Fig. (2). 


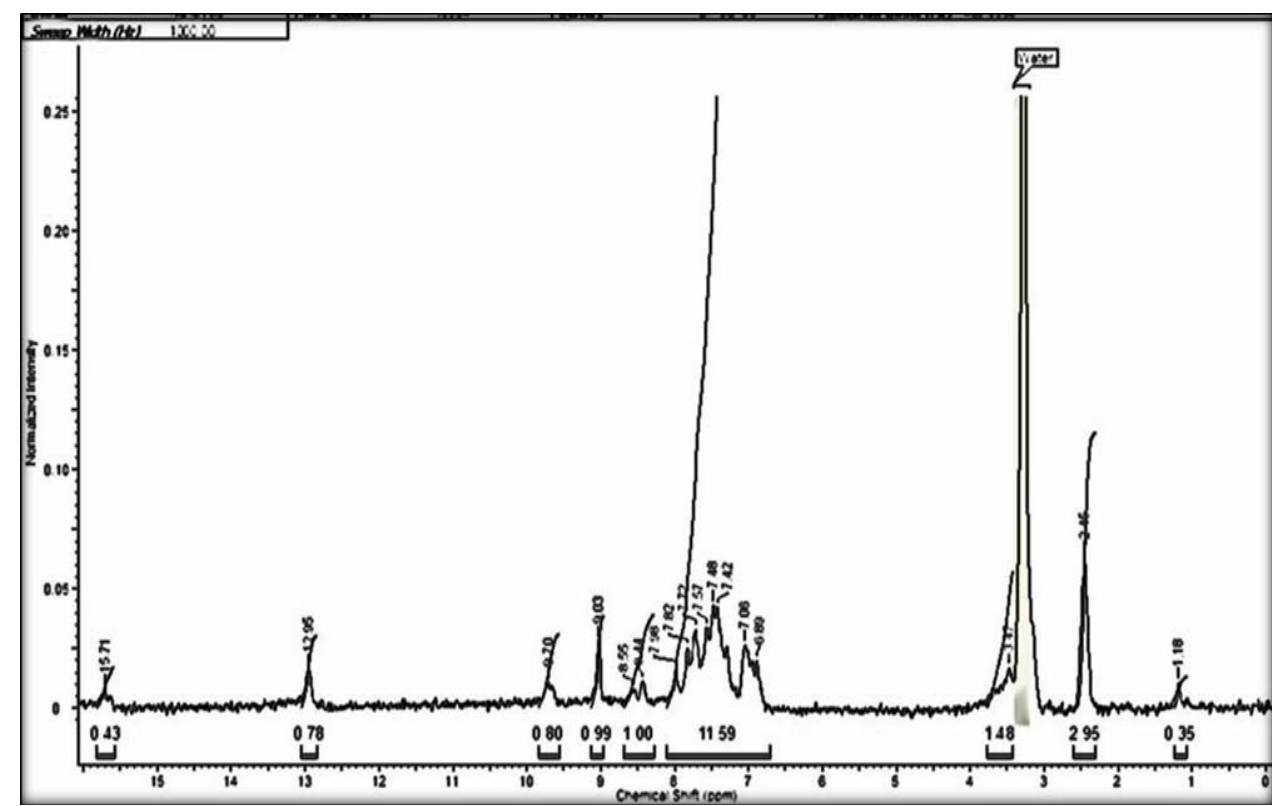

( a )

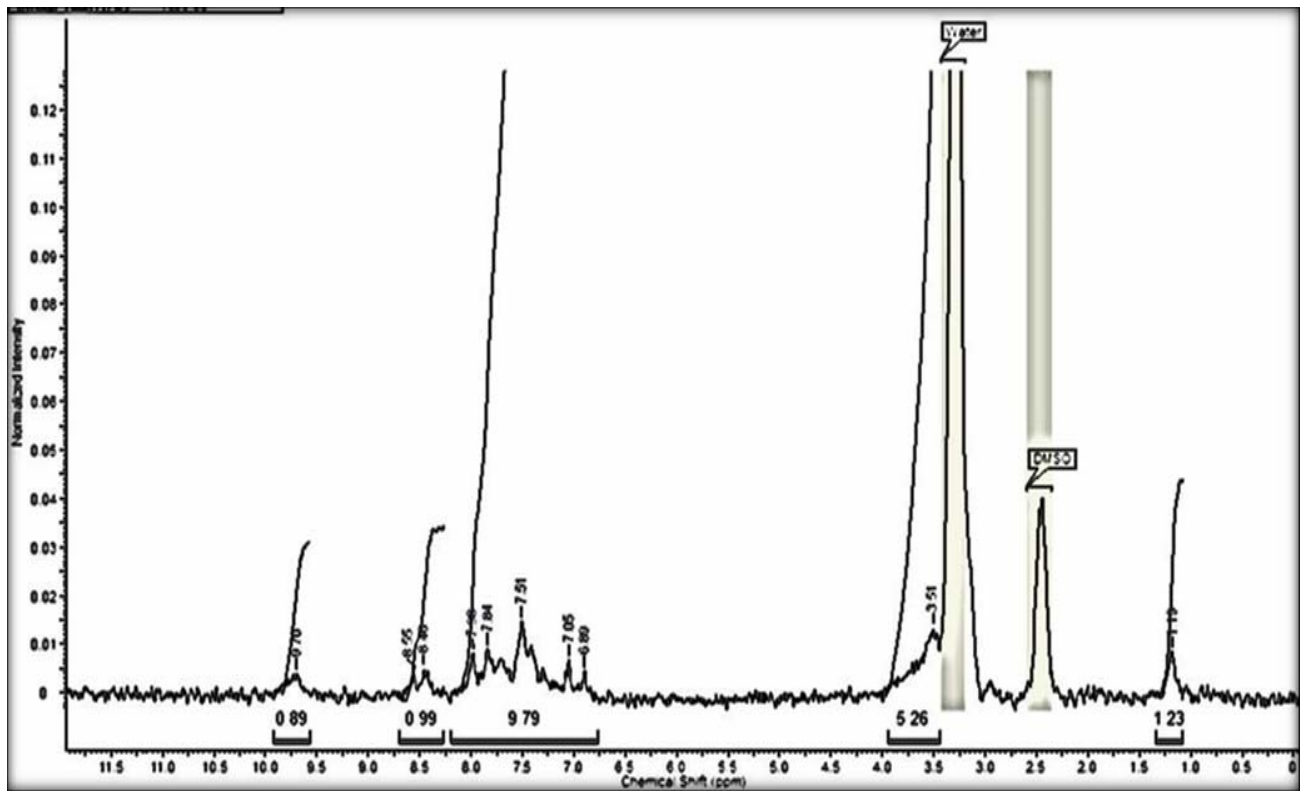

(b )

Fig. 2: ${ }^{1} \mathrm{H}$ - NMR For (a) $\mathrm{H}_{2} \mathrm{~L}^{1}$ (b) $\mathrm{H}_{2} \mathrm{~L}^{2}$ $\mathrm{s}=$ singleat,$\quad \mathrm{m}=$ multiplate

\section{Antibacterial Activity}

The tested compounds were screened in vitro for their antibacterial activity against Gram - negative and Gram - positive (Escherichia coli, Staphylococcus aureus) bacteria, the antibacterial results are given in (Table 4), compared with those of the standard drug (Ciprofloxacin). The results evidently show that the ligands and all tested complexes were active against the Gram - positive and Gram - negative bacteria on the other hand $\mathrm{Cu}$ (II) complexes (4, 8,12 and 16) exhibited higher inhibition activity as compared with their corresponding ligands and other complexes, generally the activity order against Staphylococcus aureus of the 
synthesized compounds is as follows: $\mathrm{CuL}>\mathrm{NiL}>\mathrm{CoL}>\mathrm{H}_{2} \mathrm{~L}^{2}>\mathrm{H}_{2} \mathrm{~L}^{1}>\mathrm{MnL}$, while the activity order against Escherichia coli of the synthesized compounds is as follows :- $\mathrm{CuL}$ $>\mathrm{NiL}>\mathrm{MnL}>\mathrm{CoL}>\mathrm{H}_{2} \mathrm{~L}^{2}=\mathrm{H}_{2} \mathrm{~L}^{1}$.

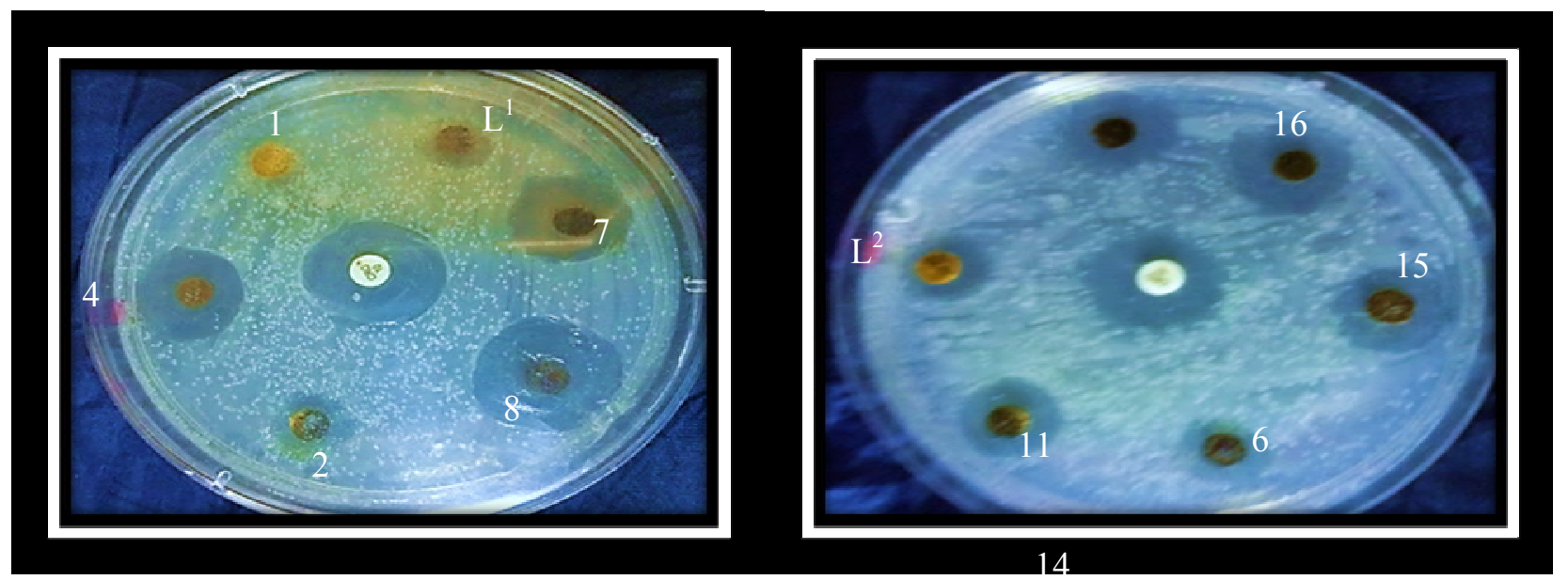

Activity of ligands and $(1,2,4,6,7,8,11,14,15,16)$ complexes against gram positive bacteria Staphylococcus aureus

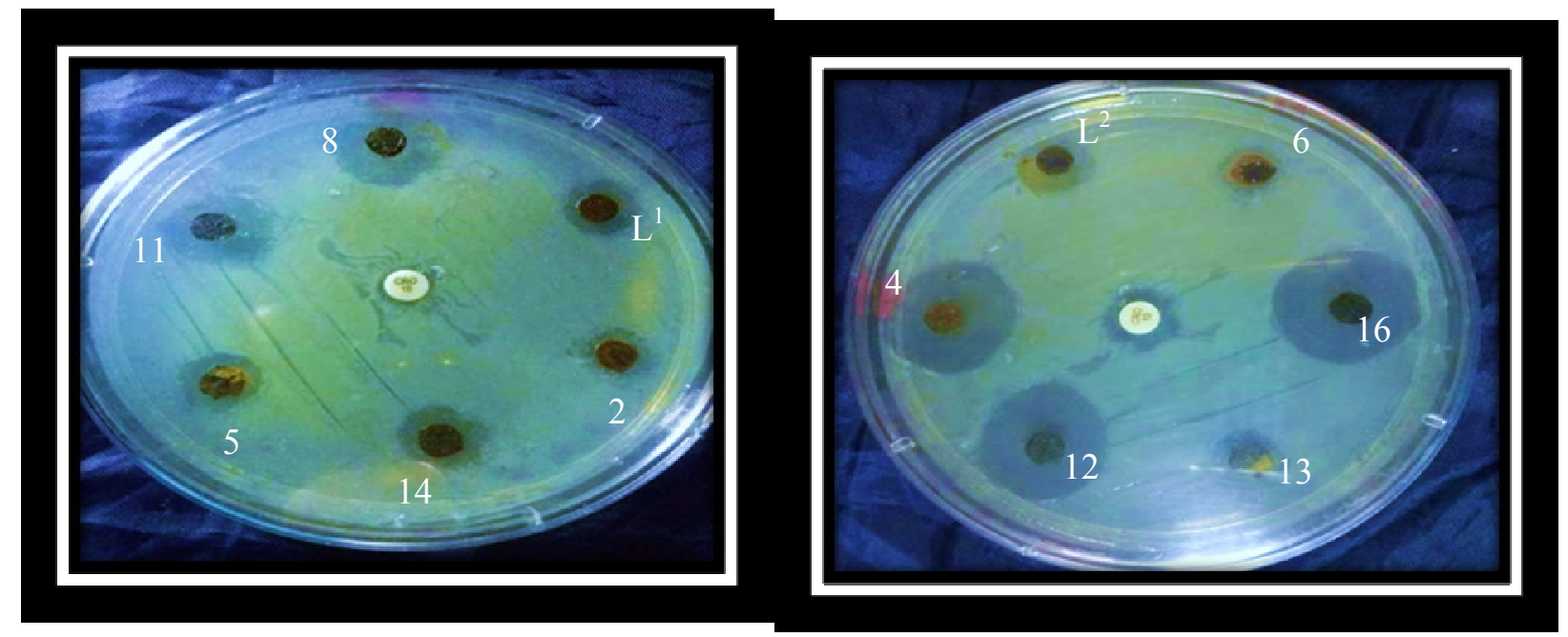

Activity of ligands and $(2,4,5,6,8,11,12,13,14,16)$ complexes against gram negative bacteria Escherichia coli

Fig. 3: Antibacterial Activity of Schiff base ligands and complexes

\section{CONCLUSION}

New Mn (II), Co (II), Ni (II), and Cu (II) complexes of unsymmetrical tetra dentate Schiff bases ligand $\left(\mathrm{H}_{2} \mathrm{~L}^{1}\right.$ and $\left.\mathrm{H}_{2} \mathrm{~L}^{2}\right)$ have been prepared and characterized by conventional measurements. The data revealed that all the complexes are dinuclear and have an either tetrahedral or octahedral geometry while $\left[\mathrm{Ni}_{2} \mathrm{~L}_{2}\right]$ complexes have square planer configuration Fig. (4). The ligands act as $\mathrm{N}_{2} \mathrm{O}_{2}$ tetra dentate dibasic chelating ligands coordinated through phenolic oxygen and imine nitrogen atoms. The ligands and their complexes were tested against Gram-positive and Gramnegative bacteria which indicate that ligands and all complexes are active against Gram-negative bacteria as compared with standard drugs. The highest activity exhibited by $\mathrm{Cu}$ (II) complexes. 

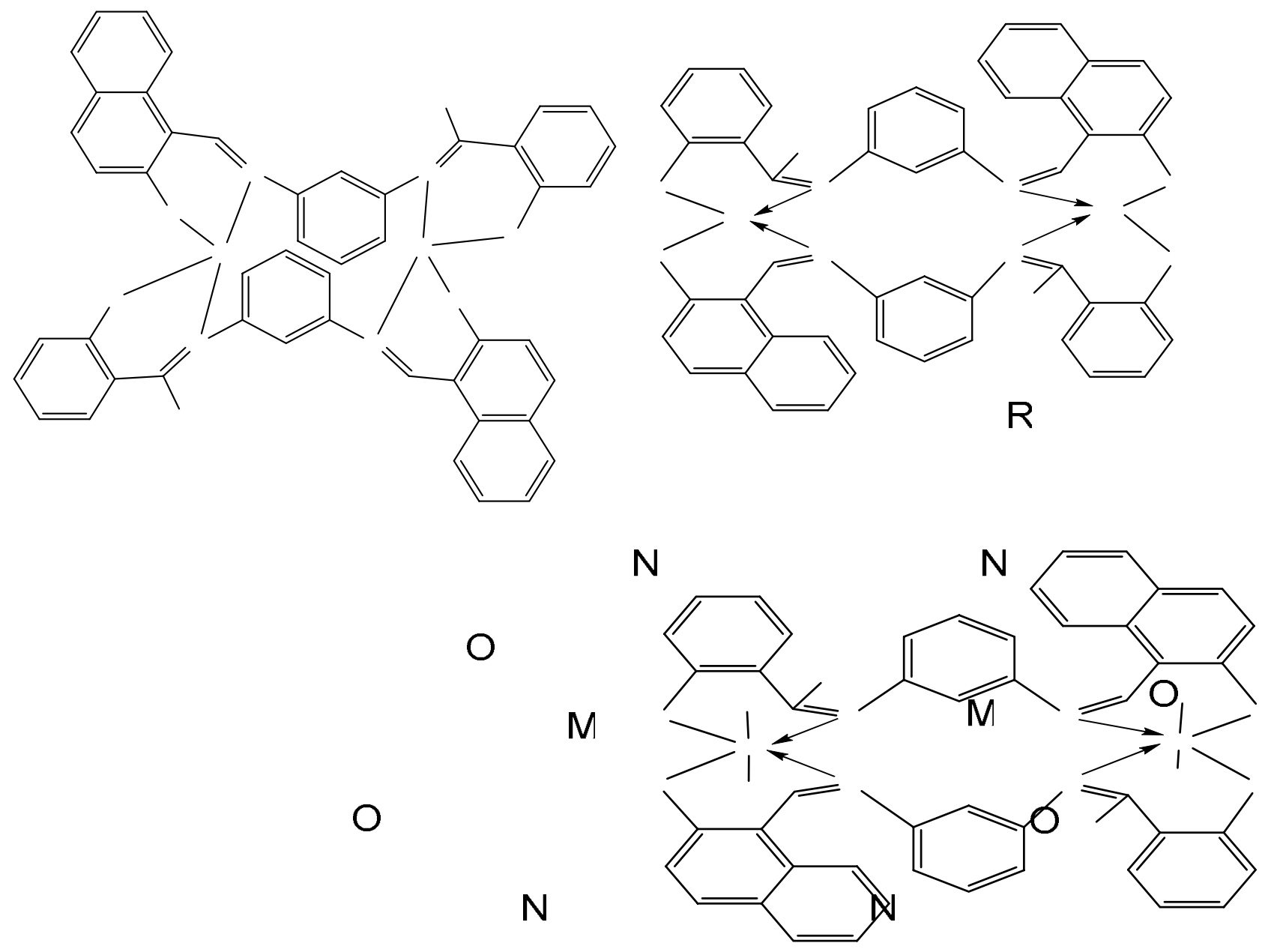

$\mathrm{R}$

Fig. 4: Suggested structure of complexes $\left[M_{2} L^{n}{ }_{2}\right]$ and $\left[M_{2} L^{n}{ }_{2}(p y)_{4}\right]$

Complexes(1, 2, 4, 9, 10, 12)

$\mathrm{M}=\mathrm{Mn}(\mathrm{II}), \mathrm{Co}(\mathrm{II})$ and $\mathrm{Cu}(\mathrm{II})$

$\mathrm{R}=\mathrm{H}, \mathrm{CH} 3$ 
Table 1: The physical properties and analytics of the ligands and their complexes

\begin{tabular}{|c|c|c|c|c|c|c|c|c|}
\hline \multirow{2}{*}{ NO. } & \multirow{2}{*}{ COMPOUND } & \multirow{2}{*}{ COLOUR } & \multirow{2}{*}{ m.p $\left(C^{0}\right)$} & \multirow{2}{*}{$\begin{array}{l}\operatorname{Am}\left(\mathrm{ohm}^{-1}\right. \\
\left.\mathbf{c m}^{2} \mathbf{m o l}^{-1}\right)\end{array}$} & \multirow{2}{*}{$\begin{array}{l}\text { M\% Calc. } \\
\text { (found) }\end{array}$} & \multicolumn{3}{|c|}{ Analysis calc. (found) \% } \\
\hline & & & & & & $\mathrm{C} \%$ & H \% & $\mathbf{N} \%$ \\
\hline $\mathrm{H}_{2} \mathrm{~L}^{1}$ & $\mathrm{C}_{24} \mathrm{H}_{18} \mathrm{~N}_{2} \mathrm{O}_{2}$ & $\begin{array}{l}\text { Green } \\
\text { yellow }\end{array}$ & 175 & - & $-\ldots-\ldots$ & $\begin{array}{c}78.67 \\
(77.73)\end{array}$ & $\begin{array}{c}4.95 \\
(4.78)\end{array}$ & $\begin{array}{c}7.65 \\
(8.18)\end{array}$ \\
\hline 1 & {$\left[\mathrm{Mn}_{2} \mathrm{~L}_{2}^{1}\right]$} & Pale yellow & 250 & 19.5 & $\begin{array}{c}13.1 \\
(13.69)\end{array}$ & $\begin{array}{c}68.74 \\
(68.89)\end{array}$ & $\begin{array}{c}3.85 \\
(3.90)\end{array}$ & $\begin{array}{c}6.68 \\
(6.08)\end{array}$ \\
\hline 2 & {$\left[\mathrm{Co}_{2} \mathrm{~L}_{2}^{1}\right]$} & Green olive & 188 & 17.6 & ------ & ------ & ------ & ------ \\
\hline 3 & {$\left[\mathrm{Ni}_{2} \mathrm{~L}_{2}^{1}\right]$} & $\begin{array}{l}\text { Orange } \\
\text { yellow }\end{array}$ & 190 & 12.8 & $\begin{array}{c}13.87 \\
(13.60) \\
\end{array}$ & & - - - & ------ \\
\hline 4 & {$\left[\mathrm{Cu}_{2} \mathrm{~L}_{2}^{1}\right]$} & Brown & 185 & 20.4 & - . - & $-\ldots$ & $-\ldots$ & - . - - \\
\hline 5 & {$\left[\mathrm{Mn}_{2} \mathrm{~L}_{2}^{1}(\mathrm{py})_{4}\right]$} & Pale yellow & 220 & 11.3 & $\begin{array}{c}9.51 \\
(9.11)\end{array}$ & $\begin{array}{c}70.70 \\
(69.98)\end{array}$ & $\begin{array}{c}4.55 \\
(4.50)\end{array}$ & $\begin{array}{c}9.70 \\
(8.89) \\
\end{array}$ \\
\hline 6 & {$\left[\mathrm{Co}_{2} \mathrm{~L}_{2}^{1}(\mathrm{py})_{4}\right]$} & Light green & 200 & 20.0 & ----- & ---- & ----- & ----- \\
\hline 7 & {$\left[\mathrm{Ni}_{2} \mathrm{~L}_{2}^{1}(\mathrm{py})_{4}\right]$} & Brown & 190 & 14.4 & ----- & ----- & ----- & ----- \\
\hline 8 & {$\left[\mathrm{Cu}_{2} \mathrm{~L}_{2}^{1}(\mathrm{py})_{4}\right]$} & Green & 195 & 19.8 & ----- & ---- & ----- & ----- \\
\hline $\mathrm{H}_{2} \mathrm{~L}^{2}$ & $\mathrm{C}_{25} \mathrm{H} 20 \mathrm{~N}_{2} \mathrm{O}_{2}$ & Brown red & 180 & $-\cdots$ & ----- & $\begin{array}{c}78.93 \\
(78.87)\end{array}$ & $\begin{array}{c}5.30 \\
(5.02)\end{array}$ & $\begin{array}{c}7.36 \\
(7.51)\end{array}$ \\
\hline 9 & {$\left[\mathrm{Mn}_{2} \mathrm{~L}_{2}^{2}\right]$} & Pale yellow & 232 & 19.7 & ----- & ---- & ----- & ---- \\
\hline 10 & {$\left[\mathrm{Co}_{2} \mathrm{~L}_{2}^{2}\right]$} & Green olive & 198 & 18.5 & $-\ldots$ & $-\ldots$ & $-\cdots$ & $-\ldots$ \\
\hline 11 & {$\left[\mathrm{Ni}_{2} \mathrm{~L}_{2}^{2}\right]$} & Olive & 193 & 19.7 & $\begin{array}{c}13.43 \\
(13.10)\end{array}$ & $\begin{array}{c}68.69 \\
(68.45)\end{array}$ & $\begin{array}{c}4.16 \\
(4.59)\end{array}$ & $\begin{array}{c}6.41 \\
(6.97)\end{array}$ \\
\hline 12 & {$\left[\mathrm{Cu}_{2} \mathrm{~L}_{2}^{2}\right]$} & Gray & 195 & 19.4 & $\begin{array}{c}14.38 \\
(14.90)\end{array}$ & $\begin{array}{c}67.93 \\
(67.87)\end{array}$ & $\begin{array}{c}4.11 \\
(4.32)\end{array}$ & $\begin{array}{c}6.34 \\
(5.77)\end{array}$ \\
\hline 13 & {$\left[\mathrm{Mn}_{2} \mathrm{~L}_{2}^{2}(\mathrm{py})_{4}\right]$} & Pale yellow & 250 & 14.9 & ----- & ----- & ----- & ----- \\
\hline 14 & {$\left[\mathrm{Co}_{2} \mathrm{~L}_{2}^{2}(\mathrm{py})_{4}\right]$} & Green & 200 & 20.0 & $\begin{array}{c}9.89 \\
(9.60)\end{array}$ & $\begin{array}{c}70.58 \\
(70.21)\end{array}$ & $\begin{array}{c}4.75 \\
(4.48)\end{array}$ & $\begin{array}{l}9.41 \\
(9.70)\end{array}$ \\
\hline 15 & {$\left[\mathrm{Ni}_{2} \mathrm{~L}_{2}^{2}(\mathrm{PY})_{4}\right]$} & $\begin{array}{c}\text { Green } \\
\text { yellow }\end{array}$ & 205 & 16.7 & ----- & ------ & ----- & ----- \\
\hline 16 & {$\left[\mathrm{Cu}_{2} \mathrm{~L}_{2}{ }_{2}(\mathrm{PY})_{4}\right]$} & $\begin{array}{l}\text { Brown } \\
\text { green }\end{array}$ & 195 & 17.5 & $\begin{array}{l}10.59 \\
(10.56)\end{array}$ & $\begin{array}{c}70.03 \\
(69.51)\end{array}$ & $\begin{array}{c}4.71 \\
(4.55)\end{array}$ & $\begin{array}{c}9.34 \\
(8.87)\end{array}$ \\
\hline
\end{tabular}


Preparation, Characterization and Biologica......

Table 2: Characteristic Infrared spectral data $\left(\mathrm{cm}^{-1}\right)$ of the ligands and their complexes

\begin{tabular}{|c|c|c|c|c|c|}
\hline NO. & $\begin{array}{c}(\mathrm{O}-\mathrm{H}) \mathrm{cm}^{-1} \\
0\end{array}$ & $\begin{array}{c}(\mathrm{C}-\mathrm{O}) \mathrm{cm}^{-1} \\
0\end{array}$ & $\begin{array}{l}\cup(C=N)_{\text {imine }} \mathrm{cm}^{-1} \\
\cup(C=N) p y-r i n g\end{array}$ & $\begin{array}{c}(\mathbf{M}-\mathbf{O}) \mathbf{c m}^{-1} \\
0\end{array}$ & $\begin{array}{c}(M-N) \mathbf{c m}^{-1} \\
0\end{array}$ \\
\hline $\mathrm{H}_{2} \mathrm{~L}^{\mathrm{I}}$ & 3465 & 1275 & 1612 & - _ - _ & $\ldots$ \\
\hline 1 & - - - - - & 1250 & 1622 & 533 & 453 \\
\hline 2 & - _. & 1270 & 1626 & 520 & 433 \\
\hline 3 & - _ _ _ _ & 1265 & 1623 & 454 & 425 \\
\hline 4 & - . - . - & 1273 & 1622 & 522 & 463 \\
\hline 5 & - & 1260 & $\begin{array}{l}1623 \\
1488\end{array}$ & 533 & 420 \\
\hline 6 & - . . - & 1255 & $\begin{array}{l}1623 \\
1488\end{array}$ & 535 & 440 \\
\hline 7 & - & 1265 & $\begin{array}{l}1622 \\
1488 \\
\end{array}$ & 518 & 433 \\
\hline 8 & - - - - & 1260 & $\begin{array}{l}1623 \\
1506 \\
\end{array}$ & 533 & 417 \\
\hline $\mathrm{H}_{2} \mathrm{~L}^{2}$ & 3498 & 1265 & 1582 & $-\ldots$ & $-\cdots$ \\
\hline 9 & - - - - - & 1255 & 1612 & 535 & 463 \\
\hline 10 & - & 1250 & 1616 & 520 & 418 \\
\hline 11 & - - - - - & 1265 & 1614 & 531 & 453 \\
\hline 12 & - - - - - & 1255 & 1607 & 491 & 452 \\
\hline 13 & - - - - - & 1260 & $\begin{array}{l}1598 \\
1488\end{array}$ & 540 & 457 \\
\hline 14 & - - - - - & 1245 & $\begin{array}{l}1619 \\
1500\end{array}$ & 530 & 420 \\
\hline 15 & - - - - - & 1250 & $\begin{array}{l}1616 \\
1489 \\
\end{array}$ & 553 & 418 \\
\hline 16 & - - - - - & 1245 & $\begin{array}{l}1616 \\
1506 \\
\end{array}$ & 520 & 418 \\
\hline
\end{tabular}


Table 3: Magnetic moments and the electronic spectral data of the ligands and their complexes

\begin{tabular}{|c|c|c|c|c|}
\hline NO. & $\mu e f f(B . M)$ & Assignment & Band maxima $\lambda\left(\mathrm{cm}^{-1}\right)$ & Structure \\
\hline $\mathrm{H}_{2} \mathrm{~L}^{1}$ & $-\ldots$ & $\mathrm{n} \rightarrow \pi^{*}, \pi \rightarrow \pi^{*}$ & 31446,37037 & ----- \\
\hline 1 & 5.75 & C.T & 27397 & $\mathrm{Td}$ \\
\hline 2 & 3.81 & ${ }^{4} \mathrm{~A}_{2}(\mathrm{~F}) \rightarrow{ }^{4} \mathrm{~T}_{1}(\mathrm{P})$, C. $\mathrm{T}$ & 16393,287501 & $\mathrm{Td}$ \\
\hline 3 & Diamagnetic & ${ }^{1} \mathrm{~A}_{1} \mathrm{~g} \rightarrow{ }^{1} \mathrm{~A}_{2} \mathrm{~g}, \quad{ }^{\mathrm{I}} \mathrm{A}_{1} \mathrm{~g} \rightarrow{ }^{\mathrm{I}} \mathrm{B}_{1} \mathrm{~g}, \mathrm{C} \cdot \mathrm{T}$ & $18518,24396,28134$ & Sq.pl \\
\hline 4 & 2.11 & ${ }^{2} \mathrm{~T}_{2} \rightarrow{ }^{2} \mathrm{E}, \mathrm{C} . \mathrm{T}$ & 10686,27954 & $\mathrm{Td}$ \\
\hline 5 & 5.85 & C.T & 277701 & $\mathrm{Oh}$ \\
\hline 6 & 5.75 & ${ }^{4} \mathrm{~A}_{2} \mathrm{~g}(\mathrm{~F}) \rightarrow{ }^{4} \mathrm{~T}_{1} \mathrm{~g}(\mathrm{~F}),{ }^{4} \mathrm{~T}_{1} \mathrm{~g}(\mathrm{~F}) \rightarrow{ }^{4} \mathrm{~T}_{1} \mathrm{~g}(\mathrm{p})$, ,C. $\mathrm{T}$ & $16806,21052,29411$ & $\mathrm{Oh}$ \\
\hline 7 & 2.92 & $\begin{array}{c}{ }^{3} \mathrm{~A}_{2} \mathrm{~g}(\mathrm{~F}) \underset{{ }^{3}}{\rightarrow}{ }^{3} \mathrm{~T}_{2} \mathrm{~g}(\mathrm{~F}),{ }^{3} \mathrm{~A}_{2} \mathrm{~g}(\mathrm{~F}) \rightarrow{ }^{3} \mathrm{~T}_{1} \mathrm{~g}(\mathrm{~F}) \\
{ }^{3} \mathrm{~T}_{2} \mathrm{~g}(\mathrm{~F}) \rightarrow{ }^{3} \mathrm{~T}_{1} \mathrm{~g}(\mathrm{p}), \mathrm{C} . \mathrm{T}\end{array}$ & $21186,24271,27691$ & Oh \\
\hline 8 & 1.83 & $\mathrm{~T}, \mathrm{C} . \quad{ }^{2} \mathrm{Eg} \rightarrow{ }^{2} \mathrm{~T}_{2} \mathrm{~g}$ & 151515,27998 & Oh \\
\hline $\mathrm{H}_{2} \mathrm{~L}^{2}$ & $\ldots \ldots$ & $\mathrm{n} \rightarrow \pi^{*}, \pi \rightarrow \pi^{*}$ & 31545,37313 & ....... \\
\hline 9 & 5.8 & C.T & 28091 & $\mathrm{Td}$ \\
\hline 10 & 3.79 & ${ }^{4} \mathrm{~A}_{2}(\mathrm{~F}) \rightarrow{ }^{4} \mathrm{~T}_{1}(\mathrm{P}), \mathrm{C} . \mathrm{T}$ & 16260,27397 & $\mathrm{Td}$ \\
\hline 11 & Diamagnetic & ${ }^{1} \mathrm{~A}_{1} \mathrm{~g} \rightarrow{ }^{1} \mathrm{~A}_{2} \mathrm{~g},{ }^{1} \mathrm{~A}_{1} \mathrm{~g} \rightarrow{ }^{1} \mathrm{~B}_{1} \mathrm{~g}, \mathrm{C} . \mathrm{T}$ & $16666,24096,29061$ & Sq.pl \\
\hline 12 & 1.87 & ${ }^{2} \mathrm{~T}_{2} \rightarrow{ }^{2} \mathrm{E}, \mathrm{C} . \mathrm{T}$ & 10566,28365 & $\mathrm{Td}$ \\
\hline 13 & 5.90 & C.T & 28559 & $\mathrm{Oh}$ \\
\hline 14 & 5.80 & ${ }^{4} \mathrm{~A}_{2} \mathrm{~g}(\mathrm{~F}) \rightarrow{ }^{4} \mathrm{~T}_{1} \mathrm{~g}(\mathrm{~F}),{ }^{4} \mathrm{~T}_{1} \mathrm{~g}(\mathrm{~F}) \rightarrow{ }^{4} \mathrm{~T}_{1} \mathrm{~g}(\mathrm{p})$, ,C. $\mathrm{T}$ & $15480,21276,26993$ & $\mathrm{Oh}$ \\
\hline 15 & 2.79 & 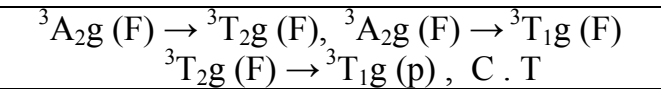 & $20618,23529,29050$ & $\mathrm{Oh}$ \\
\hline 16 & 2.20 & ${ }^{2} \mathrm{Eg} \rightarrow{ }^{2} \mathrm{~T}_{2} \mathrm{~g} \quad, \quad \mathrm{C} . \mathrm{T}$ & 15625,28792 & $\mathrm{Oh}$ \\
\hline
\end{tabular}

Table 4: The antibacterial activity of ligands and their complexes

\begin{tabular}{|c|c|c|c|}
\hline \multirow[t]{2}{*}{ NO. } & \multirow[t]{2}{*}{ COMPOUND } & Gram (+) bacteria & Gram (-) bacteria \\
\hline & & $\begin{array}{c}\text { Stphylococcus aureus } \\
(\mathbf{m} \text { m) }\end{array}$ & $\begin{array}{c}\text { Escherichia coli } \\
(\mathrm{m} \mathrm{m})\end{array}$ \\
\hline $\mathrm{H}_{2} \mathrm{~L}^{1}$ & $\mathrm{C}_{24} \mathrm{H}_{18} \mathrm{~N}_{2} \mathrm{O}_{2}$ & 7 & 14 \\
\hline 1 & {$\left[\mathrm{Mn}_{2} \mathrm{~L}_{2}^{1}\right]$} & 6 & 10 \\
\hline 2 & {$\left[\mathrm{Co}_{2} \mathrm{~L}_{2}^{1}\right]$} & 12 & 7 \\
\hline 3 & {$\left[\mathrm{Ni}_{2} \mathrm{~L}_{2}^{1}\right]$} & 15 & 12 \\
\hline 4 & {$\left[\mathrm{Cu}_{2} \mathrm{~L}_{2}^{1}\right]$} & 24 & 27 \\
\hline 5 & {$\left[\mathrm{Mn}_{2} \mathrm{~L}_{2}{ }_{2}(\mathrm{py})_{4}\right]$} & 12 & 15 \\
\hline 6 & {$\left[\mathrm{Co}_{2} \mathrm{~L}_{2}^{1}(\text { py })_{4}\right]$} & 13 & 12 \\
\hline 7 & {$\left[\mathrm{Ni}_{2} \mathrm{~L}_{2}{ }_{2}(\mathrm{py})_{4}\right]$} & 23 & 14 \\
\hline 8 & {$\left[\mathrm{Cu}_{2} \mathrm{~L}_{2}^{1}(\mathrm{py})_{4}\right]$} & 30 & 20 \\
\hline $\mathrm{H}_{2} \mathrm{~L}^{2}$ & $\mathrm{C}_{25} \mathrm{H} 20 \mathrm{~N}_{2} \mathrm{O}_{2}$ & 14 & 14 \\
\hline 9 & {$\left[\mathrm{Mn}_{2} \mathrm{~L}_{2}^{2}\right]$} & 13 & 13 \\
\hline 10 & {$\left[\mathrm{Co}_{2} \mathrm{~L}_{2}^{2}\right]$} & 16 & 12 \\
\hline 11 & {$\left[\mathrm{Ni}_{2} \mathrm{~L}_{2}^{2}\right]$} & 18 & 18 \\
\hline 12 & {$\left[\mathrm{Cu}_{2} \mathrm{~L}_{2}^{2}\right]$} & 22 & 28 \\
\hline 13 & {$\left[\mathrm{Mn}_{2} \mathrm{~L}_{2}^{2}(\text { py })_{4}\right]$} & 13 & 12 \\
\hline 14 & {$\left[\mathrm{Co}_{2} \mathrm{~L}_{2}^{2}(\mathrm{py})_{4}\right]$} & 22 & 15 \\
\hline 15 & {$\left[\mathrm{Ni}_{2} \mathrm{~L}_{2}^{2}(\mathrm{PY})_{4}\right]$} & 23 & 14 \\
\hline 16 & {$\left[\mathrm{Cu}_{2} \mathrm{~L}_{2}^{2}(\mathrm{PY})_{4}\right]$} & 27 & 30 \\
\hline Standard drug & Ciprofloxacin & 27 & 16 \\
\hline
\end{tabular}

Inhibition zone diameter (mm) (\% inhibition) : 6 -10 (27 - 45\%); 10 - 14 (45 - 64\%); 14 - 18 $(64-82 \%) ; 18-22(82-100 \%)$. 


\section{REFERENCES}

Al-Daher, A.G.M.; Mohammed, A.H. (2018). Preparation, characterization and study of ethyl pyruvate aroyl hydrazone metal complexes. Raf. J. Sci., 27(3), 100-112.

Al-Kattan, W.T.; Al-Nidaa, E.M. (2014). Synthesis and characterization of Mn(II), Co(II), Ni(II) and $\mathrm{Cu}(\mathrm{II})$ complexes with new Schiff base derived from Isophthaladehyde and 2-amino5- nitropyridine. Raf. J. Sci., 25(2), 67-75.

Alias, M.; Kassum, H.; Shkir, C. (2014). Synthesis, physical characterization and biological evaluation of Schiff base M(II) complexes. J. AAUBAS, 15, 28- 34.

Aranha, P.E.; Dosanto, M.P.; Romera, S.; Dockal, E.R. (2016). Polyhedron., Anovel Schiff base derived from the gabapentin drug and $\mathrm{Cu}(\mathrm{II})$ complex: synthesis, interaction with DNA/ protein and cytotoxic activity. J. Photo. V., 162, 34- 44.

Ceraldo, M.; Menezes, D.C.; Cavalcanti, C.A.; Santos, J.F.; Ferreira, I.P.; Wadrall, M.S. (2011). Synthesis, characterization and biological aspects of $\mathrm{Cu}(\mathrm{II})$ dithiocarbamate complexes, $\left[\mathrm{Cu}\left\{\mathrm{s}_{2} \mathrm{CNR}(\mathrm{CH} 2 \mathrm{CH} 2 \mathrm{OH})\right\}_{2}\right]$. J. Mol. Str. 988, $1-8$.

Clarke, B.; Clarke, N.; Cunningham, D.; Higgins, T.; McArdle, P.; Cholchuin, M.N.; O'Gara, M. (1998). Transition metal Schiff base complexes as ligands in tin chemistry. Part 7. reaction of organotin (IV) Lewis acids with $[\mathrm{ML}]_{2}\left[\mathrm{M}=\mathrm{Ni}, \mathrm{Cu}\right.$ and $\mathrm{Zn} ; \mathrm{H}_{2} \mathrm{~L}=\mathrm{N}, \mathrm{N}$-bis(3-methoxysalicylidend) benzene-1,3-diamine and its-1,4-diamine analog]. J. Org. Chem.,559, 55-64.

Cotton, F.A.; Wilkinson, G.; Murillo, C.A.; Bochmann, M. (1999). "Advanced in Organic Chemistry". $6^{\text {th }}$ ed., John-Wiley and Sons, New York, pp. 810- 842.

Ejidike, P.; Ajibade, A. (2015). Synthesis, characterization, antioxidant, and antibacterial studies of some metal (II) complexes of tetradentate schiff base ligand: (4E)-4-[(2-\{(E)-[1-(2,4dihydroxyphenyl)ethylidene]amino ethyl)imine]pentan-2-one. Bio. Chem. Appl. 2015, 890734, 1 - 9.

Elmali, C.T.; Elerman, A.; Svoboda, Y. (2005). Crystal structure and magnetic exchange interaction in a binuclear copper(II) Schiff base complex with a bridging $\mathrm{m}$ - phenylenediamine ligand. Z. Naturforsch, 60b, 143- 148.

El-Motaleb, A.; Ramadan, M.; Mohamed, M.; Shaban Y. (2011). Synthesis, Characterization, and tyrosinase biomimetic catalytic activity of $\mathrm{Cu}(\mathrm{II})$ complexes with Schiff base ligands derived from $\alpha$ - diketones with 2- methyl-3-amino-(3H)- quinazolin- 4-one. J. Mol. Struct., 1006, 348 -355.

Garces, f. O., King, K. A.; Watts, R.J. (1988). Synthesis, structure, electrochemistry, and photo physics of methyle-substituted phenylpyridine ortho-metalated iridium(III) Complexes. $J$. Ino. Chem. 27(10), 3464 -3471.

Gerry, W.J. (1971). The use of conductivity measurements inorganic solvents for characterization of coordination compounds. J. Coord. Chem. Rev., 7, 8 - 122.

Hernandez -Molina, R.; Mederos, A.; McCleverty, J.A.; Meyer, T.J. (2004). (Eds.), "Comprehensive Coordination Chemistry II". Elsevier Pergamon, Oxford, 1, 411p.

Hernandez-Molina, R.; Mederos, A.; Gili, P.; Dominguez, S.; Lioret, F.; Cano, J.; Julve, M.; RuizPerez,C.; Solans, X. (1997). Dimer species in dimethyl sulfoxide-water (80: 20 wlw) solution of N,N'-bis(salicylideneamine $\left(\mathrm{H}_{2} \mathrm{sal}-\mathrm{m}-\mathrm{phen}\right)$ and similar Schiff bases with $\mathrm{Cu}^{\mathrm{II}}, \mathrm{N}^{\mathrm{II}}, \mathrm{Co}^{\mathrm{II}}$ and $\mathrm{Zn}^{\mathrm{II}}$. Crystal structure of $\left.\left[\mathrm{Co}_{2} \text { (sal-m-phen }\right)_{2}\right]$. CHCl3. Dalton Transactions, 1, 4327- 4334.

Jayaseelan, P.; Prasad, S.; Vedanayaki, S.; Rajavel, R. (2010). Synthesis, spectral characterization, thermal and antimicrobial studies of new binuclear metal complexes containing tetradentate Schiff base ligand. Inter. J. Chem. Env. Pharm. Res. 1, 80-88.

Jayaseelan, P.; Prasad, S.; Vedanayaki, S.; Rajavel, R. (2011). Synthesis spectral characterization, electrochemical and antimicrobial activities of new binuclear Schiff base metal complexes derived from 3,3'-diaminobenzedine. Eur. J. Chem., 2 (4), 480. 
Kethcum, P.A. (1988). "Microbiology: Concept and Applications". John-Wiley and Sons. New York, $384 \mathrm{p}$.

Li, Y.G.; Shi, D.H.; Zhu, H.L.; Yan, H.; Ng, S.W. (2015). Synthesis, structure, unease inhibitory, and cytotoxic activities of two complexes with protocatechuic acid derivative and phenanthroline. J. Coord. Chem. 68, 1571- 1582.

Luo, X.F.; Hu, X.; Zho, X.Y.; Goh, S.H.; Li, X.D. (2003). Miscibility and interactions in blends and complexes of poly (4-methyl-5-vinylthiazole) with proton -donating polymers. Polymer., 44(18), 5285- 91.

Nagajothi, A.; Kiruthika, A.; Chitra, S.; Parameswari, K. (2013). Fe(III) Complexes with Schiff base ligands: synthesis, characterization, antimicrobial studies. India, Res. J. Chem., 3(2), $35-43$.

Osowole, A.A. (2008). Synthesis and characterization of some tetra dentate schiff base complexes and their heteroleptic analogues. J. Chem., 5(1), 130-135.

Pathan, A.H.; Naik, G.N.; Bakale, R.P.; Machakanur, S.S.; Gudasi, K.B. (2012). Ligational behavior of new mononuclearting nooethyl pyruvate schiff base towards $3 \mathrm{~d}$ metal(II)ions an emphasis on antiprpliferative and photo cleavage property. Appl. Organoment. Chem., 26, 148- 155.

Pethe, G.B.; Bansod, A.D.; Devhade, J.B.; Maldhure, A.K.; Aswar, A.S. (2017). Synthesis, spectral, thermal and biological studies of some unsymmetrical Schiff base metal complexes. India, Res. J. Chem. Sci., 7(1), 8-12.

Prakash, A.; Gangwar, M.P.; Singh, K.K.(2011). Synthesis, spectroscopy and biological studies of $\mathrm{Ni}$ (II)complexes with tetradentate schiff base $\mathrm{N}_{2} \mathrm{O}_{2}$ donor group. Int. J. Chem. Tech. Res. 3(1), 222-229.

Raman, N.; Raja, J.D.; Sakthivel, A. (2007). Synthesis, spectral characterization of Schiff base transition metal complexes: DNA cleavage and antimicroboal activity studies. J. Chem. Sci., 119, 3030310.

Ramesh, R.; Suganthy, P.K.; Natarajan, K. (1996). Synthesis, spectral and electrochemistry of $\mathrm{Ru}(\mathrm{III})$ complexes with tetradentate schiff base. Inorg. Met.-Org. Chem., 26, 47-60.

Siddiqi, K.S.; Khan, S.; Nami, S.A.A.; El-Ajaily, M.M. (2007). " Spectrochim". Acta. Part A., pp. 67-995.

Torayama, H.; Nishide, T.; Asada, H.; Fujiwara, M.; Matsushita, T. (1998). Preparation and characterization of novel cyclic tetranuclear manganese (III) complexes: $\mathrm{Mn}^{\mathrm{III}}{ }_{4}(\mathrm{x}-$ salmphen $)_{6}\left(\mathrm{x}\right.$-salmphen $\mathrm{H}_{2}=\mathrm{N}, \mathrm{N}^{\prime}$-disubstituted-salicylidene-1,3-diamin-Br)). Pol., 16(21), 3787-3794.

Turan, N.; Sekerci, M. (2009). Synthesis and characterization of $\mathrm{Co}(\mathrm{II}), \mathrm{Ni}(\mathrm{II}), \mathrm{Cd}(\mathrm{II})$ and $\mathrm{Cu}(\mathrm{II})$ complexes of bis- Schiff base obtained from 1,8-diaminonaphthalene. J. Chem. Soc., 31, $564-568$. 